Abstracta Iranica

Revue bibliographique pour le domaine irano-aryen

Volume 28 | 2007

Comptes rendus des publications de 2005

\title{
«Les migrations dans le monde turco-iranien ». CEMOTI, 39-40, 2005, pp. 137-157.
}

\section{Bernard Hourcade}

\section{Q OpenEdition}

1 Journals

\section{Édition électronique}

URL : http://journals.openedition.org/abstractairanica/10732

DOI : 10.4000/abstractairanica.10732

ISSN : 1961-960X

Éditeur :

CNRS (UMR 7528 Mondes iraniens et indiens), Éditions de l'IFRI

Édition imprimée

Date de publication : 15 mai 2007

ISSN : 0240-8910

Référence électronique

Bernard Hourcade, « « Les migrations dans le monde turco-iranien ». CEMOTI, 39-40, 2005, pp.

137-157. », Abstracta Iranica [En ligne], Volume 28 | 2007, document 510, mis en ligne le 18 septembre 2007, consulté le 25 septembre 2020. URL : http://journals.openedition.org/abstractairanica/10732 ; DOI : https://doi.org/10.4000/abstractairanica.10732

Ce document a été généré automatiquement le 25 septembre 2020.

Tous droits réservés 


\section{«Les migrations dans le monde turco-iranien ». CEMOTI, 39-40, 2005, pp. 137-157.}

\section{Bernard Hourcade}

L'A. s'interroge sur les spécificités de cette région sur le plan migratoire. Il montre que les conflits endémiques ou récurrents, ont fait de cet espace une région productrice d'émigrés internationaux et de diasporas. Arméniens, Grecs, puis Turcs, Iraniens, Irakiens kurdes puis arabes, Afghans, puis divers peuples d'Asie centrale vers la Russie...

\section{INDEX}

Thèmes : 16.3. Asie centrale

\section{AUTEURS}

\section{BERNARD HOURCADE}

CNRS / Mondes iranien et indien - Paris 